ISSN 1392-3196 / e-ISSN 2335-8947

Zemdirbyste-Agriculture, vol. 103, No. 3 (2016), p. 267-272

DOI 10.13080/z-a.2016.103.034

\title{
The variation of agronomic traits associated with breeding progress in winter barley cultivars
}

\author{
Milan MIROSAVLJEVIĆ ${ }^{1}$, Vojislava MOMČILOVIĆ ${ }^{1}$, Novo PRŽULJ ${ }^{2}$, \\ Nikola HRISTOV $^{1}$, Vladimir AĆIN ${ }^{1}$, Petar ČANAK ${ }^{1}$, Srbislav DENČIĆ ${ }^{1}$ \\ ${ }^{1}$ Institute of Field and Vegetable Crops \\ Maksima Gorkog 30, 21000 Novi Sad, Serbia \\ E-mail: milan.mirosavljevic@nsseme.com \\ ${ }^{2}$ University of Banja Luka \\ Bulevar vojvode Petra Bojovića 1A, 78000 Banja Luka, Bosnia and Herzegovina
}

\begin{abstract}
In the $20^{\text {th }}$ century, grain yield of winter barley has increased due to advances in both breeding and crop management practices. Knowledge about the association of agronomic traits with genetic gains in yield potential is necessary to improve future breeding programs. Therefore, we studied the variation in grain yield, spike length, heading date, thousand grain weight, hectolitre mass and plant height of two-rowed winter barley cultivars that were released between 1977 and 2010, in a 2-year field trial. Our results showed that most of the analyzed traits were significantly affected by the cultivar, year and cultivar-by-year interaction. The present study showed that grain yield was positively correlated with the year of release. The average rate of grain yield increase in Serbia was $46 \mathrm{~kg} \mathrm{ha}^{-1}$ per year. Further, grain yield was negatively correlated with plant height and heading date. Plant height and hectolitre mass of modern cultivars showed a significant declining trend, from the oldest to the newest cultivars. An improved understanding of the changes in agronomic traits over the last 40 years of barley breeding will help to identify targets for further breeding progress and improve the genetic potential of barley.
\end{abstract}

Key words: agronomic traits, breeding, cultivars, grain yield, Hordeum vulgare.

\section{Introduction}

As a result of the rapid decline in the cropping area and the increase in human population, constant grain yield improvement of different cereal crops, including barley, represents the primary objective of breeding programs worldwide (Araus et al., 2008). Winter barley grain yield has been steadily increasing over the past century due to advances made in plant breeding and crop management practices (Peltonen-Sainio et al., 2009). Similarly, in Serbia, both areas under barley cultivation and the genetic potential of barley cultivars have undergone substantial changes over the past century.

Based on historical data, the production and breeding of barley in Serbia can be divided into three periods. Before the late 1960s, barley was cultivated in a primitive cropping system. During this period, farmers used local landraces as seed source, or developed first cultivars from local population by individual or mass selection. The second period was characterized by a shift to production of cultivars originating from Western Europe, characterized by higher grain yield and quality compared to the local population and cultivars. Starting from the late 1970s began the third period of barley cultivation and breeding, with full affirmation and domination of cultivars developed at research institutes in the former Yugoslavia (Pržulj, Momčilović, 2006).
Over the past century of barley breeding, changes in genetic potential for grain yield (Lillemo et al., 2010) were followed by significant changes in various physiological traits. For example, the development of modern high-yielding cultivars was followed by increased number of grains per unit of land area in both barley (Abeledo et al., 2008) and wheat (Foulkes et al., 2007). Under climate condition of the Pannonian plane, Mladenov et al. (2011) found that the increase in grain number per unit of land area in wheat was associated with an increase in grain number per spike and increase in spike number per square meter, while changes in thousand grain weight did not show a clear improvement trend. Further, other agronomic traits associated with grain yield, such as plant height, thousand grain weight and heading date, have similarly undergone changes during the previous period (Bertholdsson, Brantestam, 2009).

The Pannonian zone is characterized by high year-to-year climate variability, frequent water deficit and high temperature during grain filling (Pržulj et al., 2015). Furthermore, the effect of climate change is expected to additionally increase the occurrence of undesirable seasons for cereal production (Olesen et al., 2011). Knowledge about how agronomic traits associated with genetic gains in yield potential change under the climate 
conditions of the Pannonian zone is crucial to the further improvement of barley breeding programs. Therefore, the aim of this study was to analyze variations in grain yield and other important agronomic traits of two-rowed winter barley cultivar released in Serbia during the last four decades.

\section{Materials and methods}

The plant material consisted of 12 two-rowed winter barley cultivars, including 10 cultivars widely produced in Serbia during the past four decades (19772010) and two advanced lines developed at the Institute of Field and Vegetable Crops, Serbia (Table 1). The experimental plot size was $1.0 \mathrm{~m}$ wide and $5 \mathrm{~m}$ long, with $0.1 \mathrm{~m}$ spacing between rows, and a planting density of 450 grains per $\mathrm{m}^{2}$. The trials were conducted during two growing seasons (2012-2013 and 2013-2014) at Rimski Šančevi experimental field $\left(45^{\circ} 20^{\prime}\right.$ N $19^{\circ} 51^{\prime}$ E) near Novi Sad, Serbia. A randomized complete block design with three replications was used. Each year the plots were rotated with soybean (Glycine max L.). Standard agricultural practices were conducted in both seasons. Nitrogen $(\mathrm{N})$ fertilizer was applied in two rates: $45 \mathrm{~kg} \mathrm{ha}^{-1}$ before sowing (NPK 15:15:15, $300 \mathrm{~kg} \mathrm{ha}^{-1}$ ) and $45 \mathrm{~kg} \mathrm{ha}^{-1}$ (calcium ammonium nitrate, N 27\%) at tillering stage (late February or early March). Diseases and insects were controlled by spraying pesticides at the rates recommended by manufacturers.

Table 1. Name, year of release and pedigree of 12 winter barley cultivars developed in Serbia over the past 40 years

\begin{tabular}{lcl}
\hline Cultivar & Year of release & \multicolumn{1}{c}{ Pedigree } \\
\hline Novosadski 183 & 1977 & Ager/Emir \\
Novosadski 293 & 1982 & FR 33/NS 185-2 \\
Novosadski 295 & 1982 & FR 33/NS 190 \\
Novosadski 311 & 1985 & NS 185-2/FR 33 \\
Novosadski 331 & 1985 & NS 185-2/2*FR 33 \\
L.150/88 & 1988 & Aksamit/NS 188//Sonja \\
L.147/94 & 1994 & Nepal 81/2*TU10-76//Novosadski 293 \\
Novosadski 519 & 1998 & Rodnik/Corona \\
Novosadski 525 & 1999 & NS Ranij-1/Novosadski 293//NS 327/3/Sladoran \\
Novosadski 565 & 2003 & Sonate/Danko \\
Novosadski 595 & 2007 & Sonate/Novosadski 525 \\
NS Pinon & 2010 & Novosadski 525/Tiffany//Angora/Vanessa/3/Metal/Korsö \\
\hline
\end{tabular}

The crop was machine-harvested and grain yield $\left(\mathrm{t} \mathrm{ha}^{-1}\right)$ was adjusted to $14 \%$ moisture. Thousand grain weight $(\mathrm{g})$ was determined by measuring three sets of 300 grains per plot and expressed as the weight of 1000 grains. Hectolitre mass $\left(\mathrm{kg} \mathrm{hl}^{-1}\right)$ was determined by measuring a known volume of the natural seed sample. Heading date (days) was calculated as the number of days from $1^{\text {st }}$ January to the heading date. Heading date was recorded at the day when at least $50 \%$ of the spikes in a plot had emerged fully (growth stage 55) (Zadoks et al., 1974). Plant height $(\mathrm{cm})$ and spike length $(\mathrm{cm})$ were recorded for each plot or the mean of 10 randomly selected plants in the inner rows of each plot.

Data were processed using a two-way analysis of variance. Means were compared using Tuckey's multiple range test. Principal component analysis (PCA) was used to determine interdependence between the traits. All analyses were performed in STATISTICA 10.

Weather conditions. Weather records (decade rainfall and average temperatures) were obtained from a meteorological station placed at the same location and reported as mean decade data together with 45 year averages for temperature and rainfall (Fig. 1). In the 2012-2013 growing season, the weather conditions in the winter period were similar to the long-term average, while in the following season the winter was mild with extreme drought. Optimal conditions during the spring 2013 and 2014, namely increased daily temperatures and abundant precipitations, favoured a vigorous plant growth. Excessive rainfall and an average temperature accompanied grain development in May of 2013 and 2014. In both growing seasons during June, grain filling

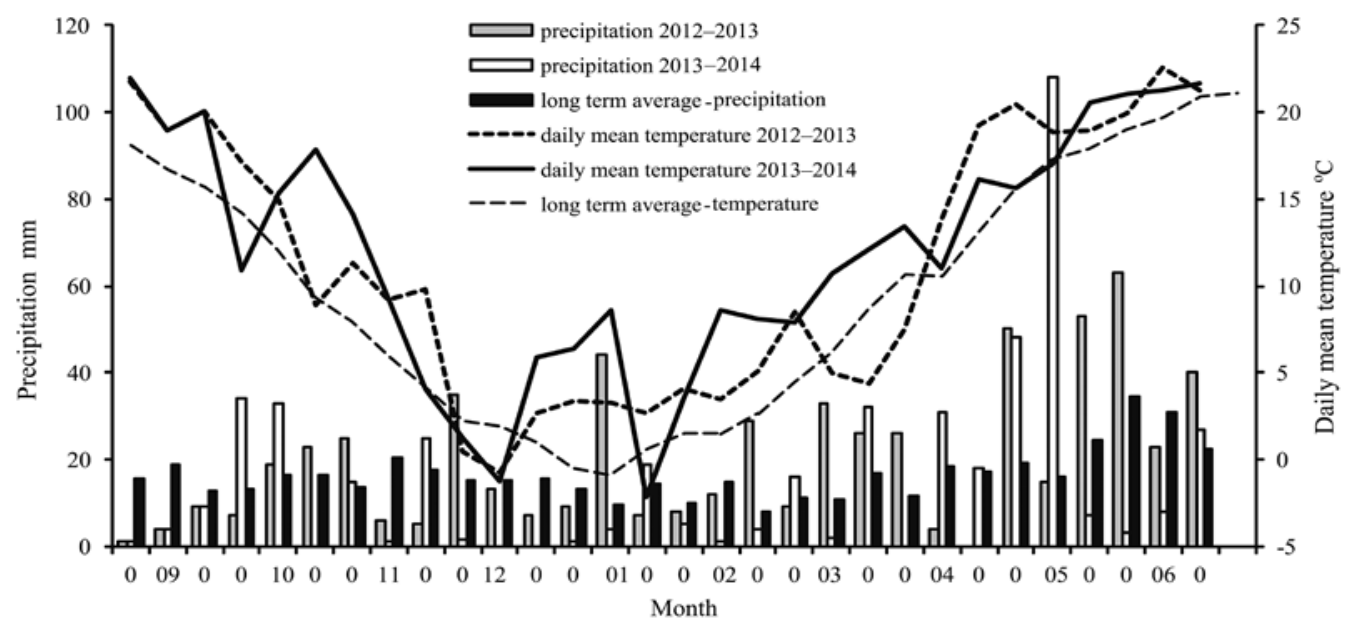

Figure 1. Ten-day period average temperature and precipitation for the 2012-2013 and 2013-2014 growing season and long term average (1968-2013) 
of barley cultivars occurred under high daily mean temperatures over long term average, with maximum day temperatures exceeding $35^{\circ} \mathrm{C}$.

\section{Results and discussion}

Different agronomic traits (grain yield, heading date, spike length, plant height, hectolitre mass and thousand grain weight) of the 12 barley cultivars from Serbia included in this trial are shown in Table 2. Most of the analyzed traits were significantly affected by the influence of cultivar $(\mathrm{C})$, year $(\mathrm{Y})$ and cultivar-by-year interaction $(\mathrm{C} \times \mathrm{Y})$.

Yield of different barley cultivars varied from 8030 to $10700 \mathrm{~kg} \mathrm{ha}^{-1}$. The mean grain yield of all cultivars was $9173 \mathrm{~kg} \mathrm{ha}^{-1}$ (Table 2). In cereal breeding, grain yield represents one of the most important and complex traits, and during the development of new cultivars, the continuous grain yield improvement remains a top priority (Yan et al., 2007). The present study showed that grain yield was positively correlated with the year of release. The average rate of grain yield increase per year in Serbia was $46 \mathrm{~kg} \mathrm{ha}^{-1}$ (Fig. 3D). Similar results of genetic improvement per year of release in barley were previously reported by Rijk et al. (2013) for conditions of the Netherland and Laidig et al. (2014) for Germany. Also, a positive trend of grain yield increase was found for wheat in Serbia (Mladenov et al., 2011) and other small grain crops worldwide (Araus et al., 2008).

Further, the association between grain yield and other agronomic traits is illustrated by the biplot of the principal component analysis (PCA) (Fig. 2). The first PCA explained $41.22 \%$ of total variation, while the second PCA explained $19.06 \%$. Together, both axes accounted for $60.28 \%$ of the total variation in the data. According to the biplot, PCA1 relates predominantly to plant height and hectolitre mass, while PCA2 was mostly related to spike length. According to this biplot, strong negative association was found between grain yield and plant height, and grain yield and heading date, as indicated by the obtuse angle. Yield was additionally negatively associated with hectolitre mass and spike

Table 2. Mean values and analysis of variance (significance) for different agronomic traits of 12 winter barley cultivars developed in Serbia over past 40 years

\begin{tabular}{|c|c|c|c|c|c|c|}
\hline Cultivar & $\begin{array}{c}\text { Heading date } \\
\text { days }\end{array}$ & $\begin{array}{l}\text { Spike length } \\
\mathrm{cm}\end{array}$ & $\begin{array}{c}\text { Plant height } \\
\mathrm{cm}\end{array}$ & $\begin{array}{l}\text { Hectolitre mass } \\
\mathrm{kg} \mathrm{hl}^{-1}\end{array}$ & $\begin{array}{c}\text { Thousand grain } \\
\text { weight } \mathrm{g}\end{array}$ & $\begin{array}{c}\text { Grain yield } \\
\mathrm{kg} \mathrm{ha}^{-1}\end{array}$ \\
\hline Novosadski 183 & $121 \mathrm{~b}$ & $9.9 \mathrm{~cd}$ & $100.0 \mathrm{abc}$ & $76.1 \mathrm{a}$ & $44.3 \mathrm{~cd}$ & $9036 \mathrm{bcd}$ \\
\hline Novosadski 293 & $120 \mathrm{bc}$ & $9.5 \mathrm{de}$ & $100.5 \mathrm{ab}$ & $74.9 \mathrm{ab}$ & $44.7 \mathrm{bcd}$ & 8299 de \\
\hline Novosadski 295 & $125 \mathrm{a}$ & $9.5 \mathrm{de}$ & $105.5 \mathrm{a}$ & $75.4 \mathrm{a}$ & $45.5 \mathrm{abcd}$ & $8030 \mathrm{e}$ \\
\hline Novosadski 311 & $119 \mathrm{bc}$ & $9.5 \mathrm{de}$ & $95.5 \mathrm{bcd}$ & $74.7 \mathrm{ab}$ & $44.6 \mathrm{bcd}$ & $8950 \mathrm{bcd}$ \\
\hline Novosadski 331 & $118 \mathrm{c}$ & $9.0 \mathrm{e}$ & $97.0 \mathrm{bcd}$ & $73.9 \mathrm{ab}$ & $43.1 \mathrm{~d}$ & $9513 \mathrm{ab}$ \\
\hline L. $150 / 88$ & $120 \mathrm{bc}$ & $9.0 \mathrm{e}$ & 98.0 abcd & $74.9 \mathrm{ab}$ & $44.6 \mathrm{bcd}$ & $8930 \mathrm{bcd}$ \\
\hline L. $147 / 94$ & $121 \mathrm{bc}$ & $11.0 \mathrm{ab}$ & $97.0 \mathrm{bcd}$ & $73.5 \mathrm{ab}$ & $45.7 \mathrm{abcd}$ & 8620 cde \\
\hline Novosadski 519 & $119 \mathrm{bc}$ & $10.5 \mathrm{bc}$ & $91.0 \mathrm{~d}$ & $73.6 \mathrm{ab}$ & $44.6 \mathrm{bcd}$ & $9371 \mathrm{abc}$ \\
\hline Novosadski 525 & $119 \mathrm{bc}$ & $11.5 \mathrm{a}$ & $93.5 \mathrm{bcd}$ & $74.6 \mathrm{ab}$ & $47.3 \mathrm{abc}$ & $9422 \mathrm{ab}$ \\
\hline Novosadski 565 & $121 \mathrm{~b}$ & $10.5 \mathrm{bc}$ & $94.5 \mathrm{bcd}$ & $74.0 \mathrm{ab}$ & $47.7 \mathrm{ab}$ & $9954 \mathrm{a}$ \\
\hline Novosadski 595 & $119 \mathrm{bc}$ & $10.0 \mathrm{~cd}$ & $90.5 \mathrm{~d}$ & $73.2 \mathrm{ab}$ & $46.0 \mathrm{abcd}$ & $9878 \mathrm{a}$ \\
\hline NS Pinon & $120 \mathrm{bc}$ & $9.5 \mathrm{de}$ & $92.5 \mathrm{~cd}$ & $72.4 \mathrm{~b}$ & $48.1 \mathrm{a}$ & $10070 \mathrm{a}$ \\
\hline Average & 120 & 9.9 & 96.3 & 74.2 & 45.2 & 9173 \\
\hline $2012-2013$ & $119 \mathrm{~b}$ & $9.89 \mathrm{a}$ & $94.5 \mathrm{~b}$ & $73.7 \mathrm{~b}$ & $47.6 \mathrm{a}$ & $9011 \mathrm{~b}$ \\
\hline $2013-2014$ & $121 \mathrm{a}$ & $10.0 \mathrm{a}$ & $98.1 \mathrm{a}$ & $74.8 \mathrm{a}$ & $43.4 \mathrm{~b}$ & $9335 \mathrm{a}$ \\
\hline Cultivar (C) & $* *$ & $* *$ & $* *$ & $* *$ & $* *$ & $* *$ \\
\hline Year $(Y)$ & $* *$ & ns & $* *$ & $* *$ & $* *$ & $* *$ \\
\hline $\mathrm{C} \times \mathrm{Y}$ & $* *$ & $* *$ & $* *$ & ns & $* *$ & $*$ \\
\hline
\end{tabular}

$* *$ - significance at 0.01 probability level, $*$ - significance at 0.05 probability level; ns - non significant

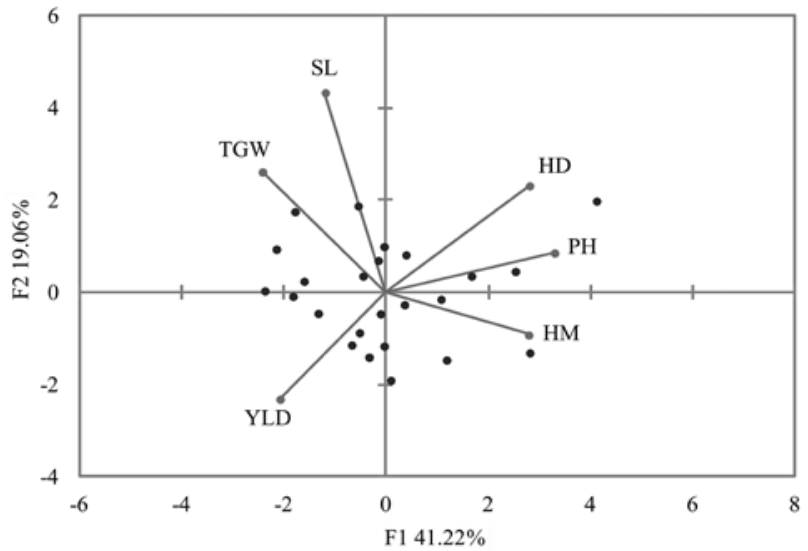

SL - spike length, TGW - thousand grain weight, YLD - grain yield, HD - heading date, $\mathrm{PH}$ - plant height, HM - hectolitre mass

Figure 2. Principal component analysis (PCA) of trait association in two-rowed winter barley across two growing seasons length. Generally, grain yield had a near zero or no association with thousand grain weight.

Optimal heading date is a significant trait determining cultivar adaptation to particular environments (Borràs-Gelonch et al., 2010). It was observed that the average heading date was 2 days later in 2013-2014 compared to 2012-2013. Also, a clear difference between cultivars was recorded in heading date, ranging from 118 days for 'Novosadski 331' released in 1998, to 125 days for 'Novosadski 295' released in 1982. Although heading date varied significantly between cultivars, no clear improvement trend according to the year of release was observed (data not shown). In addition, in oats, heading date was not significantly correlated with the year of release (Peltonen-Sainio et al., 2007). Despite the absence of a clear trend in heading date respective to breeding, Foulkes et al. (2009) reported that the increase in duration of stem elongation remains a significant goal in modern cereal breeding. Due to high association between the duration of stem elongation phase and final grain number, the prolongation of this phase is suggested as a potential method for further grain yield improvement (Borràs et al., 2009). 
According to Figure 2, heading date was negatively associated with grain yield, indicating that barley cultivars with a long period prior to heading are not suitable for semi-arid conditions of the Pannonian plane. In such conditions, grain filling of late heading date cultivars often occurs in unfavourable environments characterized by high temperatures and water deficit. On the other hand, Pržulj and Momčilović (2006) stated that very early barley cultivars had lower yield potential and are not suitable for climate conditions in Pannonian plane. These cultivars had a short vegetation period and could not accumulate sufficient level of assimilate for grain growth during pre- and post-anthesis period (Mirosavljević et al., 2015 b). Therefore, medium early cultivars have an optimal phenological development for conditions of the Pannonian plane and are more suitable for large scale production.

As a result of positive association with grain number per spike, spike length is one of the most important yield components in breeding for increased grain number per spike and yield in six- and two-rowed barley (Madic et al., 2009). Average of spike length in this study was $9.9 \mathrm{~cm}$. On average, 'Novosadski 525' and L.147/94 had the highest spike length, while the lowest was recorded in L.150/88, 'Novosadski 331', 'NS Pinon', 'Novosadski 293', 'Novosadski 295' and 'Novosadski 311'. However, our results showed that correlation coefficients between the year of cultivar release and spike length were statistically non-significant (data not shown), while the relationship between spike length and grain yield was slightly negative (Fig. 2). Therefore, barley breeders should be more focused on the improvement of spike density, to achieve further grain number per spike and grain yield increase (Pržulj, Momčilović, 2006).

In addition to the increase in grain yield, the improvement of malting quality is a significant aim in barley breeding. Malting quality is a complex trait that consists of several components. The main objectives for malting barley breeding are the improvement of grain quality traits such as malt extract and protein content, and grain physical traits including grain formation and weight
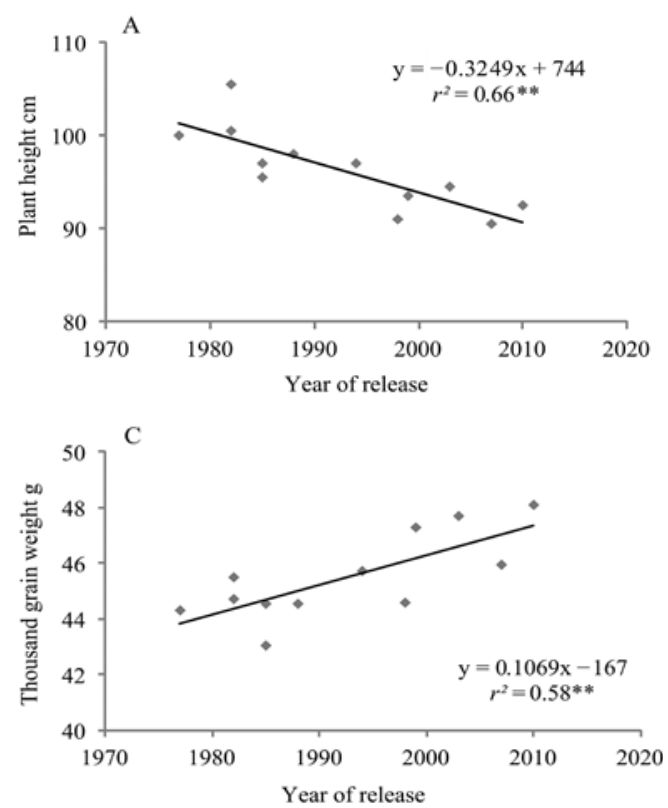

and glume content (Matthies et al., 2014). It should be emphasized that during the process of barley breeding, grain quality is mainly tested in later generations, which additionally underlines the importance of grain weight and size in development of new malting barley cultivars.

Variation in thousand grain weight is under strong influence of genetic and non-genetic factors (Pržulj et al., 2014). Our results also showed that Y, C and C $\times$ $Y$ significantly affected thousand grain weight. The mean thousand grain weight of different barley cultivars used in this study was $47.6 \mathrm{~g}$ in 2012-2013 and $43.4 \mathrm{~g}$ in 20132014. Cultivars 'NS Pinon', followed by 'Novosadski 565' and 'Novosadski 525', had the highest thousand grain weight. Further, the year of release was significantly correlated with thousand grain weight (Fig. 3C) and over the past four decades of breeding, barley thousand grain weight increased by $0.107 \mathrm{~g}_{\text {year }}{ }^{-1}$. Conversely, Bertholdsson and Brantestam (2009) reported a trend of linear decrease in thousand grain weight in winter barley registered in different decades.

PCA showed that grain yield had no relationship with thousand grain weight. The absence of a relationship between grain yield and thousand grain weight can be explained by the observation that in the last decades grain yield improvement was closely correlated to the increase of grain number per unit area both in barley (Bingham et al., 2012) and wheat (Sanchez-Garcia et al., 2012), and was not associated with the increase of grain weight (Zhou et al., 2014). Although we found that grain yield was not associated with thousand grain weight, the malting industry will continue to impose additional criteria regarding development of new cultivars with its strict quality requirements. Therefore, new barley cultivars should have increased grain number per unit area and should retain high grain weight and quality.

In general, plant height is an important trait for cereal production, and in this study it was affected by the year (Y), cultivar (C) and their interaction (C $\times \mathrm{Y})$. These results are in agreement with reports by other authors for spring and winter barley (Pržulj et al., 2014; Mirosavljević et al., 2015 a). In our study, the
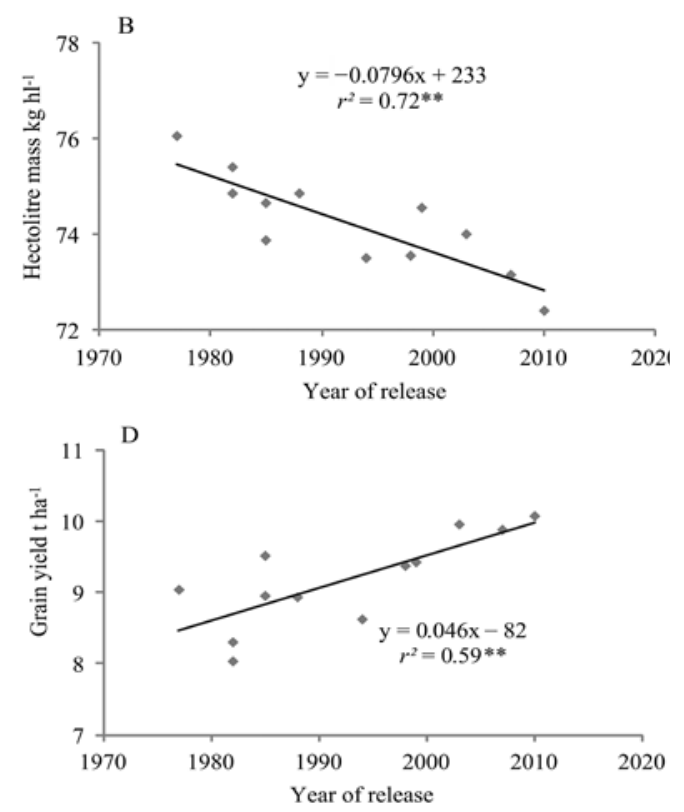

Note. Determination coefficient $\left(r^{2}\right)$ and probabilities are given $* *-P<0.01$.

Figure 3. Linear regression on year of release for plant height (A), hectolitre mass (B), thousand grain weight (C) and grain yield (D) for the set of 12 cultivars released from 1977 to 2010 
plant height of different cultivars varied across years, ranging from $105.5 \mathrm{~cm}$ for cultivar released in 1982 ('Novosadski 295') to $90.5 \mathrm{~cm}$ for the cultivar released in 2007 ('Novosadski 595'). Plant height is positively associated with susceptibility to lodging, and high plants often had reduced grain yield and quality (Berry et al., 2007). Figure 2 shows the negative relationship between plant height and grain yield. The reduction of plant height represented an important goal during the $20^{\text {th }}$ century in barley (Bertholdsson, Brantestam, 2009) and bread wheat (Diederichsen et al., 2013). Our results suggest that the decrease in plant height still remains an important goal in barley breeding programs. According to Figure $3 \mathrm{~A}$, plant height of modern cultivars showed a decreasing trend from the oldest to the newest, with an average decrease of $0.32 \mathrm{~cm}$ per year of release. It has been stated that the plant height of modern barley cultivars is within the optimum range $(70-100 \mathrm{~cm})$ for optimum grain yield, and barley breeders should not further decrease plant height below these values (Foulkes et al., 2009).

Although hectolitre mass has lost on significance in the past decades, it is still an important indicator of barley quality. Fox et al. $(2006 ; 2007)$ found positive association between hectolitre mass and different malt and feed quality. Variation in hectolitre mass was significantly affected by $\mathrm{C}$ and $\mathrm{Y}$, while the influence of $\mathrm{C} \times \mathrm{Y}$ was not significant. Among the tested cultivars, old barley cultivar 'Novosadski 183' had the highest average hectolitre mass $\left(76.1 \mathrm{~kg} \mathrm{hl}^{-1}\right)$, while modern 'NS Pinon' had the lowest $\left(72.4 \mathrm{~kg} \mathrm{hl}^{-1}\right)$. Although the differences between the cultivars were small, hectolitre mass showed a slight but significant decreasing trend in respect to the year of release (Fig. 3B). The average rate of hectolitre mass reduction per year of release was $0.03 \mathrm{~kg} \mathrm{ha}^{-1}$ per year.

Apart from the increase in thousand grain weight and reduction in plant height, one of the potential goals in the cereal breeding program should be to increase the above ground plant biomass (Araus et al., 2008). Modern cultivars have already achieved high values of harvest index, and further improvement of barley and wheat cannot be associated with additional harvest index increase (Foulkes et al., 2007). Therefore, Zhou et al. (2014) suggested that further improvement of grain yield potential should be achieved by increasing the biomass production, while maintaining or even increasing the harvest index.

\section{Conclusions}

1. Barley grain yield was positively correlated with the year of release. The average rate of grain yield increase for the period 1977-2010 was $46 \mathrm{~kg} \mathrm{ha}^{-1}$ per year of release. These results indicate that increase of grain yield was the main objective of barley breeding, and will remain so in the development of new cultivars.

2. Under the conditions of the Pannonian plane, the development of new barley two-rowed cultivars was followed by the increase in thousand grain weight, and decrease in plant height and hectolitre mass. However, there was no significant correlation between heading date and spike length with the year of cultivar release. As a result of high demands of malting industry and crop management, barley breeding should be directed toward development of new cultivars characterized by decreased plant height and good grain quality.

3. A better understanding of the changes in the agronomic traits over 40 years of barley breeding helps us to identify targets for further breeding programs, with the aim of increasing the grain yield potential of modern barley cultivars.
4. Further improvement of modern barley cultivars should be achieved by integration of conventional plant breeding with modern molecular markers technology.

\section{Acknowledgements}

This paper presents the results of the project TR31066 "Modern breeding of small grains for present and future needs", supported by the Ministry of Education, Science and Technological Development of the Republic of Serbia.

Received 13042016

Accepted 06072016

\section{References}

Abeledo L. G., Calderini D. F., Slafer G. A. 2008. Nitrogen economy in old and modern malting barleys. Field Crops Research, 106: 171-178 http://dx.doi.org/10.1016/j.fcr.2007.11.006

Araus J. L., Slafer G. A., Royo C., Serret M. D. 2008. Breeding for yield potential and stress adaptation in cereals. Critical Reviews in Plant Science. 27: 377-412 http://dx.doi.org/10.1080/07352680802467736

Berry P. M., Sylvester-Bradley R., Berry S. 2007. Ideotype design for lodging-resistant wheat. Euphytica. 154: 165-179 http://dx.doi.org/10.1007/s10681-006-9284-3

Bertholdsson N.-O., Brantestam A. K. 2009. A century of Nordic barley breeding-effects on early vigour root and shoot growth, straw length, harvest index and grain weight. European Journal of Agronomy. 30: 266-274 http://dx.doi.org/10.1016/j.eja.2008.12.003

Bingham I. J., Karley A. J., White P. J., Thomas W. T. B., Russell J. R. 2012. Analysis of improvements in nitrogen use efficiency associated with 75 years of spring barley breeding. European Journal of Agronomy. 42: 49-58 http://dx.doi.org/10.1016/j.eja.2011.10.003

Borràs G., Romagosa I., van Eeuwijk F., Slafer G. A. 2009. Genetic variability in the duration of pre-heading phases and relationships with leaf appearance and tillering dynamics in a barlev population. Field Crops Research. 113: 95-104 http://dx.doi.org/10.1016/j.fcr.2009.03.012

Borràs-Gelonch G., Salfer G. A., Casas A., van Eeuwijk F., Romagosa I. 2010. Genetic control of pre-heading phases and other traits related to development in a double haploid barley population (Hordeum vulgare L.). Field Crops Research. 119: 36-47 http://dx.doi.org/10.1016/j.fcr.2010.06.013

Diederichsen A., Solberg S., Jeppson S. 2013. Morphological changes in Nordic spring wheat (Triticum aestivum L.) landraces and cultivars released from 1892 to 1994 . Genetic Resources and Crop Evolution. 60 (2): 569-585 http://dx.doi.org/10.1007/s10722-012-9858-y

Foulkes M. J., Snape J. W., Shearman V. J., Reynolds M. P., Gaju O., Sylvester-Bradley R. 2007. Genetic progress in yield potential in wheat: Recent advances and future prospects. Journal of Agricultural Science, 145: 17-29 http://dx.doi.org/10.1017/S0021859607006740

Foulkes M. J., Reynolds M. P., Sylvester-Bradley R. 2009. Genetic improvement of grain crops: yield potential. Sadras V. O., Calderini D. F. (eds.) Crop physiology: applications for genetic improvement and agronomy. San Diego. USA. p. 355-385 http://dx.doi.org/10.1016/b978-0-12-374431-9.00015-3

Fox G. P., Kelly A. M., Poulsen D. M. E., Inkerman P. A., Henry R. J. 2006. Genetic and environmental effects on selecting improved barley grain size in dry environments. Journal of Cereal Science. 43: 198-208 http://dx.doi.org/10.1016/j.jcs.2005.08.004

Fox G. P., Nguyen L., Bowman J., Poulsen D., Inkerman A., Henry R. J. 2007. Relationship between hardness genes and quality in barley (Hordeum vulgare). Journal of the Institute of Brewing. 113 (1): 87-95 http://dx.doi.org/10.1002/j.2050-0416.2007.tb00261.x 
Laidig F., Piepho H.-P., Drobek T., Meyer U. 2014. Genetic and non-genetic long-term trends of 12 different crops in German official variety performance trials and on-farm yield trends. Theoretical and Annlied Genetics. 127: 2599-2617 http://dx.doi.org/10.1007/s00122-014-2402-z

Lillemo M., Reitan L., Bjørnstad C. 2010. Increasing impact of plant breeding on barley yields in central Norway from 1946 to 2008. Plant Breeding, 129: 484-490

Madic M., Knežević D., Paunović A., Zečević V. 2009 Inheritance of stem height and second-internode length in barlev hybrids. Genetika, 41 (3): 229-236 http://dx.doi.org/10.2298/GENSR0903229M

Matthies I. E., Malosetti M., Röder M. S., van Eeuwijk F. 2014. Genome-wide association mapping for kernel and malting quality traits using historical european barley records. PLoS ONE, 9(11): 1-15 http://dx.doi.org/10.1371/journal.pone.0110046

Mirosavljević M., Pržulj N., Canak P., Momčilović V., Aćin V., Jocković B., Hristov N., Mladenov N. 2015 (a). Relationship between grain yield and agronomic traits in winter barley. Ratarstvo i Povrtarstvo. 52 (2): 74-79 http://dx.doi.org/10.5937/ratpov52-7860

Mirosavljević M., Pržulj N., Momčilović V., Hristov N., Maksimović I. 2015 (b). Dry matter accumulation and remobilization in winter barley as affected by genotype and sowing date. Genetika. 47 (2): 751-763 http://dx.doi.org/10.2298/GÉNSR1502751M

Mladenov N., Hristov N., Kondic-Spika A., Djuric V., Jevtic R., Mladenov V. 2011. Breeding progress in grain yield of winter wheat cultivars grown at different nitrogen levels in semiarid conditions. Breeding Science, 61 (3): 260-268 http://dx.doi.org/10.1270/jsbbs.61.260

Olesen J. E., 'Irnka M., Kersebaum K. C., Skjelvag A. O., Seguin B., Peltonen-Sainio P., Rossi F., Kozyra J., Micale F. 2011. Impacts and adaptation of European crop production systems to climate change. Euronean Journal of Agronomy, 34: 96-112 http://dx.doi.org/10.1016/j.eja.2010.11.003

Peltonen-Sainio P., Kangas A., Salo Y., Jauhiainen L. 2007. Grain number dominates grain weight in cereal yield determination: evidence basing on 30 years' multi-location trials. Field Crons Research. 100: 179-188 http://dx.doi.org/10.1016/j.fer.2006.07.002

Peltonen-Sainio P., Jauhiainen L., Laurila I. P. 2009. Cereal yield trends in northern European conditions: changes in yield potential and its realisation. Field Crons Research, 110: 85-90 http://dx.doi.org/10.1016/j.fcr.2008.07.007

Pržulj N., Momčilović V. 2006. Barley breeding at Institute of field and vegetable crops. Zbornik radova Instituta za ratarstvo i povrtarstvo, 42 (1): $361-370$

Pržulj N., Momčilović V., Simić J., Mirosavljević M. 2014. Effect of growing season and variety on quality of spring two-rowed barlev. Genetika, 46 (1): 59-73 http://dx.doi.org/10.2298/GENSR1401059P

Pržulj N., Mirosavljević M., Ćanak P., Zorić M., Boćanski J. 2015. Evaluation of spring barley performance by biplot analvsis. Cereal Research Communications. 43 (4): 692 $703 \mathrm{http} / / / \mathrm{dx}$. doi.org/10.1556/0806.43.2015.018

Rijk B., van Ittersum M., Withagen J. 2013. Genetic progress in Dutch cron vields. Field Crons Research, 149: 262-268 http://dx.doi.org/10.1016/j.fcr.2013.05.008

Sanchez-Garcia M., Royo C., Aparicio N., Martin-Sanchez J. A., Álvaro F. 2012. Genetic improvement of bread wheat yield and associated traits in Spain during the $20^{\text {th }}$ century. Journal of A gricultural Science. 151 (1): 105-118 http://dx.doi.org/10.1017/S0021859612000330

Yan W., Molnar S., Fregeau-Reid J., McElroy A., Tinker N. A. 2007. Associations among oat traits and their responses to the environment in North America. Journal of Crop Imnrovement. 20: 1-29 http://dx.doi.org/10.1300/J411v20n01_01

Zadoks J. C., Chang T. T., Konzak C. F. 1974. A decimal code for the growth stage of cereals. Weed Research. 14: 415-421 http://dx.doi.org/10.1111/j.1365-3180.1974.tb01084.x

Zhou B., Sanz-Sáez A., Elazab A., Shen I., Sánchez-Bragado R., Bort J., Serret M. D., Araus J. L. 2014. Physiological traits contributed to the recent increase in yield potential of winter wheat from Henan Province, China. Journal of Integrative Plant Biology, 56: 492-504 http://dx.doi.org/10.1111/jipb.12148

ISSN 1392-3196 / e-ISSN 2335-8947

Zemdirbyste-Agriculture, vol. 103, No. 3 (2016), p. 267-272

DOI $10.13080 /$ z-a.2016.103.034

\title{
Žieminių miežių veislių agronominių savybių kaita susijusi su selekcijos pažanga
}

\author{
M. Mirosavljević ${ }^{1}$, V. Momčilović ${ }^{1}$, N. Pržulj ${ }^{2}$, N. Hristov ${ }^{1}$, V. Aćin ${ }^{1}$, P. Čanak ${ }^{1}$, S. Denčić ${ }^{1}$ \\ ${ }^{1}$ Serbijos lauko ir daržo augalų institutas \\ ${ }^{2}$ Banja Luka universitetas, Bosnija ir Hercegovina
}

\section{Santrauka}

Dvidešimtajame amžiuje žieminių miežių derlius padidèjo dèl selekcijos ir augalų auginimo agrotechnikos pažangos. Žinios apie agronominių savybių ryšị su genetiniais pasiekimais, susijusiais su derliaus potencialu, yra svarbios siekiant patobulinti ateities selekcines programas. Tuo tikslu buvo atliktas dvejų metų lauko bandymas, kurio metu tirtas derliaus, varpos ilgio, plaukejjimo datos, tūkstančio grūdų masès, saiko svorio ir augalų aukščio varijavimas dvieilèse žieminių miežių veislèse, išvestose 1977-2010 m. Tyrimų rezultatai parodè, kad daugumai iš tirtų agronominiu požymių didelę ịtaką turèjo veislè, metai ir veislès bei metų sąveika. Taip pat nustatyta, kad grūdų derlius teigiamai koreliavo su veislès išvedimo metais. Vidutinis miežiu grūdu derliaus padidejjimas Serbijoje buvo $46 \mathrm{~kg} \mathrm{ha}^{-1}$ per metus. Be to, grūdų derlius neigiamai koreliavo su augalų aukščiu ir plaukejjimo data. Šiuolaikinių veislių augalų aukštis ir saiko svoris parodè esminę mažèjimo tendenciją nuo seniausių iki naujausių veislių. Geresnis miežių agronominių savybių pokyčių per pastaruosius 40 selekcijos metų supratimas padès nustatyti ateities selekcijos pažangos tikslus ir pagerins miežių genetini potencialą.

Reikšminiai žodžiai: agronominiai požymiai, grūdų derlius, Hordeum vulgare, selekcija, veislès.

Please use the following format when citing the article:

Mirosavljevic M., Momčilović V., Pržulj N., Hristov N., Aćin V., Čanak P., Denčić S. The variation of agronomic traits associated with breeding progress in winter barley cultivars. Zemdirbyste-Agriculture, 103 (3): 267-272 DOI 10.13080/z-a.2016.103.034 